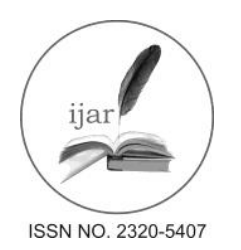

Journal homepage: http://www.journalijar.com

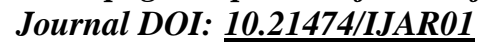

INTERNATIONAL JOURNAL

OF ADVANCED RESEARCH

RESEARCH ARTICLE

\title{
EVALUATION OF DIFFERENT MODALITIES OF SURGICAL TREATMENT IN EXTRACAPSULAR FRACTURE OF PROXIMAL FEMUR.
}

\author{
Dr Arvind Kumar, Dr Sudhir Kumar Rawat, Dr Ravi Kumar, Dr Umesh Chaudhari, Dr Umang Sanghvi, Dr \\ Wasim Ahmed.
}

\section{Manuscript Info}

Manuscript History:

Received: 15 February 2016

Final Accepted: 19 March 2016

Published Online: April 2016

Key words:

Extracapsular Proximal Femur

Fracture, D.H.S, P.F.N.

*Corresponding Author

.............................

Dr Arvind Kumar.

\begin{abstract}
INTRODUCTION:The incidence of fracture around hip has increased a lot with gradual increase in general life expectancy of the population. The fracture around hip accounts for about one third of all hospitalized patients. Among the different type of fractures around hip extracapsular fracture of proximal end femur are most common. The incidence is more than the fracture femoral neck proper. In elderly, $90 \%$ of extracapsular fracture results from trivial injury while in young adult it results from high energy trauma like motor vehicle accident. The incidence of extracapsular fracture in elderly is more than fracture in young adult because of several factors like osteoporosis, decreased muscle power, poor vision. These fractures are associated with a substantial morbidity and mortality and account for a large amount of expenditure in the treatment. Now days mode of treatment is changing from conservative to surgical, so it need to study different treatment modality forextracapsular fracture ofproximal femur.

AIM AND OBJECTIVE:To assess and evaluate different surgicalmodality of management in extracapsular fracture of proximal femur.

MATERIAL AND METHOD:This was prospective analytic study, conducted at the Department of Orthopaedics and Traumatology, D.M.C.H., Laheriasarai, Darbhanga in year 2007 to 2010. Total 32 Cases were selected by inclusion and exclusion criteria. Out of 32 cases, 12 cases were treated with PFN and 20 with DHS. All the operations were done under image intensifier control. Follow up of the patients were done up to $48^{\text {th }}$ postoperative weeks for the assessment of functional and anatomical result.

OBSERVATION AND RESULT:Present series is of 32 cases, of it $43.75 \%$ were male and 56.25\% were female, Average age was 50-70 years. Most common mode of injury was trivial injury/minor slip comprising $46.87 \%$ patients in which $31.25 \%$ female and $15.62 \%$ male. Second commonest mode of injury was Road Traffic accident comprising $25 \%$, in which $15.62 \%$ were male and $9.37 \%$ were female. The \# was classified by EVAN'S classification, $59.37 \%$ cases were of stable fracture, 28.12 of unstable type and $12.50 \%$ were subtrochanteric type fracture. \# were reduced under image intensifier and fixed with D.H.S or P.F.N. by 3rd postoperative weeks, in PFN group $91.66 \%$ of cases were partial weight bearing with crutches, But in DHS group by $6^{\text {th }}$ postoperative weeks $75 \%$ of cases partial weight bearing with help of crutches, full weight bearing in P.F.N group was 12-18 wk and in D.H.S group it was 18-24 wk. $8 \%$ in P.F.N group and $15 \%$ in D.H.S group had superficial infection while $10 \%$ in D.H.S group had deep infection, no deep infection in P.F.N group.

CONCLUSION:In PFN group patients, blood loss and soft tissue dissection was less as compared to DHS group patients. Within first 3 months PFN allowed a faster postoperative restoration of walking ability as compared to DHS. It was found that there was no major difference between PFN and DHS treatment group long term follow-up in clinical and radiological features.
\end{abstract}

Copy Right, IJAR, 2016,. All rights reserved.

\section{Introduction:-}

The incidence of fracture around hip has increased a lot with gradual increase in general life expectancy of the population. The fracture around hip accounts for about one third of all hospitalized patients. Among the different 
type of fractures around hip extracapsular fracture of proximal end femur are most common. The incidence is more than the fracture femoral neck proper. In elderly, $90 \%$ of extracapsular fracture results from trivial injury while in young adult it results from high energy trauma like motor vehicle accident. The incidence of extracapsular fracture in elderly is more than fracture in young adult because of several factors like osteoporosis, decreased muscle power, poor vision. These fractures are associated with a substantial morbidity and mortality and account for a large amount of expenditure in the treatment.

Elderly patients with extracapsular fracture and their hospital stay had prime concern of orthopaedic surgeon around the globe.

\section{The treatment of extracapsular fracture had advanced greatly in the last three decades.}

In early nineteenth century, patients suffering from extracapsular fracture were simply placed in skeletal traction in bed for prolonged period of time until healing occurred (usually 10-12 weeks). This was followed by a lengthy program of ambulation training. The blood supply in this region is good so the fractures united but healing was generally accompanied by varus deformity and shortening because of the inability of the traction to effectively counteracts the deformity muscle force. Prolonged period of bed rest in traction increases the incidence of morbidity and mortality. Later on, operative treatment of these fracture with various type of fixation devices, was developed which allowed early rehabilitation and offered the patient better chance for functional recovery.

Early weight bearing and mobilization put great demands on both the implant and osteoporotic bone. Because, very elderly patients start full weight bearing immediately despite repeated instructions against it, the Dynamic Hip Screw (DHS Richards) and Proximal Femoral Nailing (PFN) is the favoured implant. Dynamic Hip screw is a lag screw, which is biomechanically superior to various compression hip screw systems developed during recent years (Regazzoni 1985). The sliding mechanism secures intrafragmentary contact is there even if resorption of the fracture end should occur (Svenninges et al. 1984). The Dynamic Hip Screw is a unique implant. It facilitates application of compression across the fracture line at the time of surgery; also acts as a rail on which axial movement is feasible to achieve impaction of the fracture fragments with the passage of time. It is strong enough to withstand large bending loads and also protects the fixation against disruptive torque transmitted by the shaft in internal or external rotation. Dynamic action of DHS results in reduced incidence of cut-out and of penetration of the nail into the hip joint, as opposed to static devices.

\section{Proximal femoral nailing has recently been developed for fixation of extracapsular fracture of proximal femur.}

\section{This implant offers several advantage like}

(1) It is an intramedullary fixation device, theoretically provides more efficient load transfer than does a sliding hip screw

(2) Insertion of device require both theoretically and practically less operative time and less soft tissue dissection

(3) The shorter lever arm of the device can be expected to decrease tensile strain on the implant, there by decreasing the risk of failure of implant.

Since 1970's, almost all the surgeons all over the world have opined that fractures around proximal end of femur should be operated routinely. Therefore internal fixation of trochanteric fracture has become established as the treatment of choice. The arguments favouring internal fixation has been based on such promises as the lower mortality rate, the need of less nursing care, early release from hospital, prevention of bed sores and other medical complications, early ambulation and better end results.

The goal of operative treatment is to restore anatomy (anatomical reduction), strong and stable fixation of the fracture fragments and resultant union afterwards within reasonable period of time.

Common internal fixation devices:

(1) Fixed angle devices;-Jewett fixed angle nail plate (1941),Fixed angle nail plate of Holt (1963),95 degree DCS plate

(2) Sliding nail plate;-DHS(Richards), AO type plate and Medoff's Sliding plate (MSP)

(3) Intrameullary devices;-Ender nail, Gamma locking nail, Proximal femoral nailing(PFN) 
In present day surgical practice, it is important to know whether a fracture is stable or unstable: The answer to this question will guide the reduction technique, the type of fixation to be used, and the postoperative management. A good classification must provide information on the fractures potential of being anatomically reduced with good apposition of the fragments. Also, it should be possible to tell, in the light of the classification, whether a particular fracture is likely to become secondarily displaced after fixation; this information must be available before the patient is allowed to weight-bear.

Over the past 50 years, much has been written on the different methods of the fixation of extracapsular fracture. In order to appreciate the results, one needs to Study the fracture management modalities involved. The result will help to treat the patients of extracapsular fractures by best surgical modality in current phase of time.

Material and method:

Patients with extracapsular fracture upper end of femur attending orthopaedics emergency and Orthopaedic OPD of D.M.C.H. Laheriasarai were included in the present study. Extracapsular fracture includes intertrochanteric fracture and subtrochanteric fracture. Total 32 Cases were selected by inclusion and exclusion criteria. Out of 32 cases, 12 cases were treated with PFN and 20 with DHS.

\section{Method (operative procedure) for PFN:}

- Under spinal/epidural anesthesia

- patient is kept in supine position on radiolucent fracture table

- Affected leg put on foot rest of fracture table.

- Closed reduction was tried under image guidance. If close reduction was not successful open reduction was done.

- Anatomical reduction and securing good fracture fixation of the patient on the operating table was essential for easy handing and a good surgical result.

- Palpate the Greater trochanter and make a $5 \mathrm{~cm}$ long incision starting from tip of the Greater trochanter and going proximal to it.

- Make a parallel incision in fascia of gluteus medius and split the Gluteus Medius in line with its fibers.

- entry portal was made with the help of a bone awl just medial to tip of greater trochanter and the position of awl was checked under image control.

- A guide wire is passed after removal of the awl and position of guide wire confirmed under image on both view (AP and Lateral).

- With the help of reamer medullary canal was reamed over guide wire. The required size nail was introduced with the help of nail introducer.

- Insertion of proximal locking screw - Make a stab incision on lateral part of thigh and insert the drill sleeve with trocar through the proximal locking screw hole in the insertion jig assembly.

- The position and direction of guide pin is checked with the help of image on both AP and Lateral views. Choose a position in the caudal area of the femoral head so that both proximal screws can be inserted, Guide pin is passed $5 \mathrm{~mm}$ deeper into head then femoral head screw is planned.

- Proximal screw were inserted.

- Insertion of distal locking screw - distal locking is performed with $5 \mathrm{~mm}$ locking bolt using the cranial locking hole only for static locking and caudal hole for dynamic locking.

- Wound closure - After through irrigation with diluted povidone iodine solution and proper haemostasis, wound is closed in layers after covering the wound with sterile dressing pad.

- Method (operative procedure) for DHS -

- Under spinal/epidural anaesthesia patient is positioned on radiolucent operating table in supine position with the affected leg placed on foot rest of fracture table.

- Opposite leg is either put on foot rest of fracture table or placed on flexed, abducted position with the help of additional attachment of fracture table.

- Fracture was reduced preoperatively under image intensifier control.

- The reduction is checked under image in both AP and Lateral Views. After satisfactory reduction, painting and draping is done from Loin to just below the knee.

- An 8-10 cm straight lateral incision is made starting at base of greater trochanter and extending distally.

- The incision is deepened through the subcutaneous tissue and the iliotibial band is incised along the line of its fibers. Care being taken to remain posterior to the Tensor fascia lata muscles. The covering fascia of vastuslateralis is incised and vastuslateralis muscle split to expose the proximal Part of femur. 
- Insertion of guide wire - A threaded tip guide wire is inserted with the help of fixed angle guide aiming the guide wire towards the apex of the femoral head. The entry of guide wire made at about $2 \mathrm{~cm}$ below the vastuslateralis ridge, central placement of guide wire is confirmed in both AP and lateral views.

- The depth gauze is placed over guide wire to measure the required length to be reamed.

- The DHS triple reamer is used for reaming for screw

- The DHS lag screw of desired length is inserted with the help of coupling screw driver.

- The length of DHS lag screw is selected so that the tip of screw was $10 \mathrm{~mm}$ from the joint. After this, the DHS plate is inserted onto the assembly and the coupling screw and guide shaft is removed.

- With the help of an impactor the plate is sealed against the cortex of femur.

- Plate clamp/bone holder is used to secure the plate to the shaft.

- Cortical screw is inserted after drilling and tapping of lateral and medial cortex.

- Closure of wound - Thorough irrigation of wound is done with diluted povidone iodine solution. After proper haemostasis wound is closed in layers.

- Postoperative care - After recovery from anaesthesia the patient was kept under strict observation for the first 24 hrs.

- Postoperative follow up- From the first postoperative day patient was encouraged to do exercise for hip and knee joint.

- Stitches were removed on $14^{\text {th } / 15 \text { th }}$ postoperative day. Patients were allowed for partial weight bearing with the help of crutches after $3^{\text {rd }}$ week in simple stable fracture and after 6 weeks in comminuted posteromedial cortex of trochanter.

Clinical and radiological evaluations were done at regular interval of 6 th, $12^{\text {th }}, 18^{\text {th }}$ and $24^{\text {th }}$ weeks, and 48 weeks.

\section{Parameters for observation -}

Following parameters were observed in current series:-

\section{Clinical}

1. Pain/Swelling (if any)

2. $\quad$ Rate of infection (in \%)

3. Malalignment (in degree)

a. Coxavara/Valga

b. Internal/external rotation

4. Shortening (in $\mathrm{Cm}$ )

5. Range of motion of knee and hip (in degree)

a. Flexion deficit

b. Extension deficit

6. Average hospital stay (in days)

7. Duration of union (in weeks)

8. Pain free walking

a. crutch walking

b. Independent walking

c. Pre Trauma stage walking

\section{Radiological}

In addition to AP view of pelvis showing both hip, AP and Lateral view of operated hip including thigh was taken at $6^{\text {th }}, 12^{\text {th }}, 18^{\text {th }}, 24^{\text {th }}$ and $48^{\text {th }}$ week post operatively to note the following :-

1. Alignment of bone at fracture site and its nature

2. Position of nail and lag screw in neck (intact, cut out, broken)

3. Collapse of the fracture gap.

4. Status of callus and union at different time interval of follow up

5. Restoration of trabecular pattern at fracture site.

\section{OBERVATION:}

The present study is done on 32 cases of extracapsuar fracture of proximal of femur, admitted and treated in Orthopaedic Department of Darbhanga Medical College Hospital, Laheriasarai, Darbhanga, during the period from April 2007 to October 2009. 
- Out of 32 cases, 20 were treated with DHS while 12 cases with PFN.

- $14(43.75 \%)$ were male and $18(56.25 \%)$ were female patients.

- Average age of patients was 51 to 70 years (60\% patients).

- Most common mode of injury was trivial injury/minor slip comprising $46.87 \%$ patients in which $31.25 \%$ female and $15.62 \%$ male.

- Second commonest mode of injury was Road Traffic accident comprising 25\%, in which $15.62 \%$ were male and $9.37 \%$ were female.

- On evan's classification 19 cases (59.37\%) were of stable type, 9 cases $(28.12 \%)$ of unstable type and 4 cases $(12.50 \%)$ were subtrochanteric type fracture.

- $\quad$ A A B L E - 1

Showing average duration of hospital stay (in days).

\begin{tabular}{|c|c|c|c|}
\hline \multirow[t]{2}{*}{ Type of fracture } & \multirow{2}{*}{$\begin{array}{l}\text { No. of } \\
\text { cases }\end{array}$} & \multicolumn{2}{|c|}{ Average duration (in days) } \\
\hline & & $\mathrm{PFN}$ & DHS \\
\hline Stable & 19 & 6 days & 11 days \\
\hline Unstable & 9 & 11 days & 16 days \\
\hline $\begin{array}{l}\text { Subtrochanteric or Reverse } \\
\text { oblique }\end{array}$ & 4 & 15 days & 20 days \\
\hline
\end{tabular}

Table showed patient treated with PFN was hospitalized for an average period of 11 days ranging from 6 - 15 days while in DHS treated patients average duration of stay were 16 days ranging from $11-20$ days.

- $\quad$ A B L E - 2Closed/ Open PFN nailing.

\begin{tabular}{|l|c|c|}
\hline \multirow{2}{*}{ Procedure } & \multicolumn{2}{|c|}{ PFN } \\
\cline { 2 - 3 } & No. of patients & Percentage \\
\hline Closed & 8 & $66.66 \%$ \\
\hline Open & 4 & $33.33 \%$ \\
\hline Total : & 12 & $100.00 \%$ \\
\hline
\end{tabular}

In majority of cases $(66.66 \%)$ closed nailing was done. Open nailing was done in 4 cases $(33.33 \%)$ where anatomical reduction by closed method was not satisfactory at the time of operation. In these cases open nailing was done for the following factors :

1. Old neglected fracture.

2. $\quad$ Long oblique spiral fracture.

3. Soft tissue interposition.

TA B L E - 3

Showing clinical and radiological follow up.

Each patient was examined clinically during each visit regarding complains, inspection, palpation, movement and measurement of injured/affected limb. Radiological evaluation was done for evidence of union, status of callus formation, measurement of neck shaft angle and failure of implant.

\begin{tabular}{|l|c|c|c|c|}
\hline \multirow{2}{*}{ Type of fracture } & \multicolumn{2}{|c|}{ PFN } & \multicolumn{2}{c|}{ DHS } \\
\cline { 2 - 5 } & Satisfactory & Unsatisfactory & Satisfactory & Unsatisfactory \\
\hline Stable & 6 & Nil & 14 & Nil \\
\hline Unstable & 3 & 1 & 4 & 1 \\
\hline $\begin{array}{l}\text { Subtrochanteric } \\
\text { or Reverse } \\
\text { oblique fracture }\end{array}$ & 2 & Nil & Nil & \\
\hline
\end{tabular}

In PFN treatment group, Position of implant was found to be satisfactory in majority of cases (Approx. 100\%) of stable type fracture. One case with unstable type had unsatisfactory result (cut out of lag screw from lat. Cortex). 
In DHS treatment group, position of implant was found to be satisfactory in majority of cases of stable type fracture .In one case with unstable type fracture had unsatisfactory result (lag screw was not positioned centrally in the neck).

In PFN treatment group, swelling at $6^{\text {th }}$ postoperative weeks at fracture site was present in 3 cases $(25 \%)$, at $12^{\text {th }}$ week in 1 case $(8.33 \%)$.

Local bony tenderness - on $6^{\text {th }}$ postoperative weeks at fracture site was present in 2 cases $(16.66 \%)$, at $12^{\text {th }}$ postoperative weeks in 1 case $(8.33 \%)$.

In DHS treatment group, swelling at $6^{\text {th }}$ postoperative week was present in 6 cases $(30 \%)$, at 12 th week in 3 cases $(15 \%)$, at $18^{\text {th }}$ week in one case $(5 \%)$ and at $24^{\text {th }}$ week there was no swelling at all.

Local bony tenderness - at $6^{\text {th }}$ postoperative weeks present in 11 cases $(55 \%)$, at $12^{\text {th }}$ weeks in 5 cases $(25 \%)$, at $18^{\text {th }}$ week in 2 cases $(10 \%)$ and at $24^{\text {th }}$ week there was no local bony tenderness at all.

TABLE 4

Showing Radiological Union.

\begin{tabular}{|c|c|c|c|c|c|c|c|}
\hline & & & \multicolumn{5}{|c|}{ No. of cases } \\
\hline & & & $6^{\text {th }}$ week & $12^{\text {th }}$ week & $\begin{array}{c}18^{\text {th }} \\
\text { week }\end{array}$ & $24^{\text {th }}$ week & $\begin{array}{l}48^{\text {th }} \\
\text { week }\end{array}$ \\
\hline \multirow[t]{4}{*}{ 1. Fracture gap } & \multirow[t]{2}{*}{ Present } & PFN & 12 & 1 & Nil & Nil & Nil \\
\hline & & DHS & 18 & 2 & 1 & Nil & Nil \\
\hline & \multirow[t]{2}{*}{ Absent } & PFN & 4 & 11 & 12 & 12 & 12 \\
\hline & & DHS & 4 & 17 & 19 & 20 & 20 \\
\hline \multirow{4}{*}{$\begin{array}{l}\text { 2. Bridging of } \\
\text { fracture gap }\end{array}$} & \multirow[t]{2}{*}{ Present } & PFN & 10 & 12 & 12 & 12 & 12 \\
\hline & & DHS & 14 & 16 & 19 & 20 & 20 \\
\hline & \multirow[t]{2}{*}{ Absent } & PFN & 2 & Nil & Nil & Nil & Nil \\
\hline & & DHS & 6 & 2 & Nil & Nil & Nil \\
\hline \multirow[t]{4}{*}{ 3. Visible callus } & \multirow[t]{2}{*}{ Present } & PFN & 10 & 12 & 12 & 12 & 12 \\
\hline & & DHS & 16 & 18 & 20 & 20 & 20 \\
\hline & \multirow[t]{2}{*}{ Absent } & PFN & 1 & Nil & Nil & Nil & Nil \\
\hline & & DHS & 3 & 1 & Nil & Nil & Nil \\
\hline \multirow{4}{*}{$\begin{array}{l}\text { 4. Trabecular } \\
\text { pattern }\end{array}$} & \multirow[t]{2}{*}{ Present } & PFN & Nil & 9 & 11 & 12 & 12 \\
\hline & & DHS & Nil & 14 & 16 & 18 & 20 \\
\hline & \multirow[t]{2}{*}{ Absent } & PFN & 12 & 3 & Nil & Nil & Nil \\
\hline & & DHS & 20 & 4 & 2 & 1 & Nil \\
\hline
\end{tabular}

Table showed, Trabecular pattern was restored in all patients around $18^{\text {th }}$ to $48^{\text {th }}$ postoperative weeks of follow up. T A B L E - 5 Showing range of movement at hospital at $12^{\text {th }}, 18^{\text {th }}, 24^{\text {th }}$ and $48^{\text {th }}$ postoperative weeks of follow up:

\begin{tabular}{|c|c|c|c|c|c|c|c|c|}
\hline \multirow{2}{*}{$\begin{array}{c}\text { Range of hip } \\
\text { movement }\end{array}$} & \multicolumn{2}{|c|}{$12^{\text {th }}$ weeks } & \multicolumn{2}{c|}{$18^{\text {th }}$ weeks } & \multicolumn{2}{|c|}{$24^{\text {th }}$ weeks } & \multicolumn{2}{|c|}{$48^{\text {th }}$ weeks } \\
\cline { 2 - 9 } & PFN & DHS & PFN & DHS & PFN & DHS & PFN & DHS \\
\hline $\begin{array}{c}\text { Full range of } \\
\text { movement }\end{array}$ & 10 & 16 & 12 & 17 & 12 & 20 & 12 & 20 \\
\hline $\begin{array}{c}5^{\circ}-10^{\circ} \text { short of full } \\
\text { range }\end{array}$ & 11 & 17 & 12 & 18 & 12 & 20 & 12 & 20 \\
\hline $\begin{array}{c}>50^{\circ} \text { of full range of } \\
\text { movement }\end{array}$ & 12 & 18 & 12 & 19 & 12 & 19 & 12 & 20 \\
\hline $\begin{array}{c}<50^{\circ} \text { of full range of } \\
\text { movement }\end{array}$ & 12 & 20 & 12 & 20 & 12 & 20 & 12 & 20 \\
\hline
\end{tabular}

Table showed, between $18^{\text {th }}$ to $24^{\text {th }}$ postoperative weeks all patients in each treatment group had full range of movement. 


\section{$\underline{\text { TA B L E }-6}$}

Showing weight bearing ability at $6^{\text {th }}, 12^{\text {th }}, 18$ th, 24 th and $48^{\text {th }}$ postoperative weeks of follow up:

\begin{tabular}{|c|c|c|c|c|}
\hline \multirow{2}{*}{$\begin{array}{c}\text { Time interval (in } \\
\text { weeks) }\end{array}$} & \multicolumn{2}{|c|}{ PFN } & \multicolumn{2}{c|}{ DHS } \\
\cline { 2 - 5 } & $\begin{array}{c}\text { Partial weight } \\
\text { bearing }\end{array}$ & $\begin{array}{c}\text { Full weight } \\
\text { bearing }\end{array}$ & $\begin{array}{c}\text { Partial weight } \\
\text { bearing }\end{array}$ & $\begin{array}{c}\text { Full weight } \\
\text { bearing }\end{array}$ \\
\hline At $6^{\text {th }}$ weeks & 11 & 1 & 15 & Nil \\
\hline At $12^{\text {th }}$ weeks & 12 & 3 & 16 & 10 \\
\hline At $18^{\text {th }}$ weeks & 12 & 12 & 20 & 16 \\
\hline At $24^{\text {th }}$ weeks & 12 & 12 & 20 & 20 \\
\hline At $48^{\text {th }}$ weeks & 12 & 12 & 20 & \\
\hline
\end{tabular}

At $6^{\text {th }}$ postoperative weeks, in PFN treatment group patients $91.66 \%$ (11 cases) out of 12 cases were taking partial weight with help of crutch. By $12^{\text {th }}$ weeks all patients walk with the help of crutch.

In DHS group, at $6^{\text {th }}$ postoperative weeks $75 \%$ (15 cases out of 20 cases) bear partial weight, by $12^{\text {th }}$ weeks $80 \%$ (16 cases out of 20 cases) and by $18^{\text {th }}$ weeks all patients bear partial weight.

In PFN group patients, full weight bearing start from $6^{\text {th }}$ postoperative weeks (in 1 patients), by $12^{\text {th }}$ week in 3 patients and by $18^{\text {th }}$ postoperative weeks all 12 patients bear full weight while in DHS group full weight bearing start from $12^{\text {th }}$ postoperative weeks and by $24^{\text {th }}$ postoperative weeks all 20 patients bear full weight.

T A B L E -7

Showing deformity after $24^{\text {th }}$ and $48^{\text {th }}$ postoperative weeks of follow up.

\begin{tabular}{|c|c|c|c|c|}
\hline \multirow{2}{*}{ Deformity } & \multicolumn{4}{|c|}{ Method } \\
\cline { 2 - 5 } & \multicolumn{2}{|c|}{ PFN } & \multicolumn{2}{c|}{ DHS } \\
\cline { 2 - 5 } & $24^{\text {th }}$ weeks & $48^{\text {th }}$ weeks & $24^{\text {th }}$ weeks & $48^{\text {th }}$ weeks \\
\hline CoxaVara & & & & \\
$0^{\circ}-10^{\circ}$ & $1(8 \%)$ & Nil & $4(20 \%)$ & $2(10 \%)$ \\
$10^{\circ}-20^{\circ}$ & Nil & Nil & $2(10 \%)$ & $1(5 \%)$ \\
$>20^{\circ}$ & Nil & Nil & Nil & Nil \\
\hline External rotation & Nil & Nil & $2(10 \%)$ & Nil \\
\hline Internal rotation & $1(8 \%)$ & Nil & $3(15 \%)$ & Nil \\
\hline
\end{tabular}

Table showed, there was 1 coxavara deformity of $0^{\circ}-10^{\circ}$ at $24^{\text {th }}$ postoperative weeks in PFN treatment group. In DHS treatment group, $4(20 \%)$ patients had coxavara $0^{\circ}-10^{\circ}$ at $24^{\text {th }}$ weeks, 2 patients at $48^{\text {th }}$ weeks. 2 patients $10^{\circ}-20^{\circ}$ coxavara deformity at $24^{\text {th }}$ weeks and 1 patient at $48^{\text {th }}$ weeks.

Coxavalga deformity was not found in any patient.

Two patients $(10 \%)$ in DHS treatment group had external rotational deformity and 3 patients $(15 \%)$ had internal rotation deformity while only one patient in PFN group had internal rotational deformity.

T A B L E -8

Showing overall complications:

\begin{tabular}{|c|c|c|}
\hline \multirow{2}{*}{ Complications } & \multicolumn{2}{|c|}{ No. of cases } \\
\hline & PFN & DHS \\
\hline 1.Nil & 9 & 12 \\
\hline 2. Infection: & & \\
\hline Superficial & $1(8 \%)$ & $3(15 \%)$ \\
\hline Deep & Nil & $2(10 \%)$ \\
\hline 3. Broken implant & Nil & $1(5 \%)$ \\
\hline 4. Pain around nail insertion site & $1(8 \%)$ & Nil \\
\hline 5. Bending of screws or cutout of lag screw & $1(8 \%)$ & Nil \\
\hline 6 Delayed union & Nil & Nil \\
\hline 7. Non-union & Nil & Nil \\
\hline
\end{tabular}


Table showed,

- $\quad$ One case (8\%) in PFN group had superficial infection while 3 patients (15\%) in DHS group had superficial infection.

- Average incidence of infection was $11.5 \%$

- There was no deep infection in PFN group while 2 cases (10\%) of DHS group had deep infection.

- In one case of DHS group, DHS plate was broken.

- $\quad$ One patient had pain around nail insertion site in PFN group.

- One elderly patient had cutout of antirotational lag screw in PFN group.

Discussion:

Extracapsular fracture proximal end of femur if not treated adequately developed coxavara deformity and shortening of the affected leg. Extracapsular area of proximal femur is made of cancellous bone with rich vascular supply. So union is not a problem in these types of fractures.

Closed/open reduction and internal fixation is the treatment of choice for extracapsular fracture now-adays.Internal fixation of trochanteric fracture is being performed for ease of nursing care, restoration of anatomy, early mobilization, decreased mortality, decreased hospitalization and early regaining of functional ability.

In western countries where all recent facilities are available, the internal fixation is carried out usually in short span of time, But in our country due to lack of recent facilities, limited number of hospital beds, limited number of operation theater working days, overcrowding of patients, limited experienced and qualified personnel , lack of patient awareness, operative fixation is obviously delayed.

In the present series, 32 cases of extracapsular fractures had been treated. Out of 32, $12(37.5 \%)$ cases were treated with PFN and 20(62.5\%) were treated with DHS; the results were tabulated and compared.

\section{Age incidence:}

In this study the average age of patients were between 21 to 80 years. The maximum patients were in the age group of 61 to 70 in male patients and in females between 51 to 60 years respectively. In this series the youngest patient was 28 year old and oldest one was 73 years.

Harrington and Johnston $(1973)^{(1)}$ reported average age of 70 years, Hunter $(1975)^{(2)}-71$ years, Kuderna

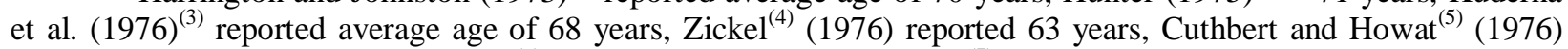
73.5 years, Poigenfurst and Schnable ${ }^{(6)}$ (1977)- 77 years, Laskin et al. ${ }^{(7)}$ (1979) reported average age of 86 years, Wilson et al. ${ }^{(8)}$ (1980) 78.2 years, Max. P. et al. ${ }^{(9)}$ (1986) 81.7 years, Domingo L.T. et al ${ }^{(10)}$ (2001) 80 years, Doub P .et $\mathrm{al}^{(11)}$ (2002) 68 years Saudan M. et $\mathrm{al}^{(12)}$ (2003) reported average age 55 years, Tyllionksi M. et al ${ }^{(13)}$ (2004) reported average age 71.3 years.

In western countries life expectancy was higher than Indians. The average life expectancy was 78 years in western countries while in India it was 64 years. Indians reached their senility earlier than western people, so these fractures were seen at an earlier age in India.

\section{Sex incidence:}

In the present study of 32 cases, 14 cases $(43.75 \%)$ were males and 18 cases $(56.25 \%)$ were females.

Sex incidence reported by different authors were as follows : Harrington and Johnston ${ }^{(1)}$ (1973) reported $42 \%$ male and $58 \%$ female, Poigenfirst and Schnable ${ }^{(6)}(1977) 17 \%$ male and 83\% female, Laskin et al ${ }^{(7)}$ (1979) reported $18 \%$ male and $82 \%$ female cases, Heyse-Moore et al. ${ }^{(14)}$ (1983) $26 \%$ male and $74 \%$ female cases, Rueger J. M. et $\mathrm{al}^{(15)}$ (1996) reported $26 \%$ male patients and $74 \%$ female patients. Reska M. et al ${ }^{(16)}$ (2006) reported 30\% male and $70 \%$ female.

In maximum number of literature there was female predominance in extracapsular fracture upper end of femur. The reason for the female predominance might be due to physiological (postmenopausal osteoporosis) and less outdoor activity leading to weakened and early fragility of bone.

\section{Mode of injury}

As different type of injury produce fracture in extracapsular region of proximal femur, it was very difficult to classify them accurately .the types of injury in this study is divided in 4 groups

(1) Road traffic accidents

(2) Major trauma

(3) Fall from height

(4) Trivial injury or minor slip, as shown in table 2. 
In first group (RTA), patient fell down or were hit by motor vehicle. In second group (major trauma), injury were produced by hard object hitting over trochanter when body was in motion. In the third group (fall from height of 3 metre or more) and in the fourth group trivial injuries like minor slip and stumble which could be due to fall on uneven or slippery surface or from the stairs or due to wrong stepping.

In this study, the maximum number of cases had history of trivial injury $(46.87 \%)$; second most common mode of injury was RTA $(25 \%)$.

The most of the female patients $(56.25 \%)$ suffered due to trivial injury. Cleereland and co-workers ${ }^{(17)}$ (1947) and Weiss and colleagues ${ }^{(18)}$ reported that trochanteric fractures occur more commonly in females because of post menopausal metabolic changes in the bone. Frangakis ${ }^{(19)}$ (1966) believed that by 65 years of age $50 \%$ of women had bone mineral content below the fracture threshold and by 85 years of age $100 \%$ women had a bone mineral content below fracture threshold. Barnes and co-workers ${ }^{(20)}$ (1976) demonstrated increasing degree of osteoporosis with advancing age, especially in women.

Most of the male patients suffered due to RTA and major trauma (21.87\%) or trivial injury or minor slip (15.62\%).

\section{Hospital Stay:}

In the present study average hospital stay for PFN treatment group patient was ranging from 16-25 days while in DHS treatment group patients from 21-30 days.

Factors affecting the average hospital stay in the present study include delayed in consent of patients to the surgical treatment and limited number of operation theatre working days in a week as compared to input of patients.

Hail and Ainscow ${ }^{(21)}$ (1981) reported average hospital stay of 40 days for the patients of intertrochanteric fractures treated with different fixed angle nail plates. They also observed 25 days average hospital stay for the cases treated with Ender's nail.

\section{Closed/ Open Proximal Femoral Nailing (PFN):}

In majority of cases (66.66) closed reduction and proximal femoral nailing were done under image control but in $33.33 \%$ cases open reduction and proximal femoral nailing were done because anatomical reduction by closed method were not satisfactory.

Following cases required open reduction and internal fixation in the present series-

1. Old neglected fracture

2. Long oblique fracture

3. Soft tissues interposition

UNION OF FRACTURE- For criteria of fracture union we follow Christopher H, Flemming et al ${ }^{(22)} \mathrm{criteria.}$ According to whom fracture union was defined as the period between operation and full weight bearing without any external support, no local bony tenderness and a radiologically healed fracture. Radiological healing of fracture was defined as the presence of callus around most of the fracture circumference with a density similar to that of the adjacent cortical bone.

In this study, hundred percent union were obtained in all cases treated by proximal femoral nailing and Dynamic hip screw (DHS-Richards)

Baker, H.R. ${ }^{(23)}$ (1960) and Sarmiento, A. ${ }^{(24)}$ (1963) reported that extracapsular fractures unite well because of good vascular supply and cancellous nature of bone. Nonunion was found to be uncommon in extracapsular fracture.

According to Mul-holland ${ }^{(25)}(1972)$ and Wilson, H.J. et $\mathrm{al}^{(26)}$ (1980) and Mariani, E.M. et al ${ }^{(27)}$ (1989): the incidence of non-union was reported to be low (1\% to $2 \%$ ).

Extracapsular fractures that were prone to non-union include comminuted unstable fractures with loss of posteromedial calcar continuity, which tend to fall into varus displacement when stabilized.

Mariani and $\operatorname{Raud}^{(28)}$ (1989) reported that 19 out of 20 patients with non-union of intertrochanteric fractures had unstable fractures with loss of posteromedial support.

\section{POST OPERATIVE WEIGHT BEARING:}

In the present study, the patients were mobilized in bed to a sitting posture in the first postoperative day to decrease the incidence of pulmonary thromboembolic and urinary tract complication. Walking with partial weight bearing with the help of crutch/walker was allowed in PFN group from $3^{\text {rd }}$ postoperative weeks and in DHS group from $6^{\text {th }}$ postoperative weeks. The average period of full weight bearing in PFN group was 12-18th postoperative weeks while in DHS group $18-24^{\text {th }}$ postoperative weeks. 
Nuber, S.et.al. ${ }^{(29)}$ (2003) observed 129 patients treated with PFN and DHS. They observed 97\% of PFN group patient bearing weight immediately after the operation and $88 \%$ of DHS group patient for the same. Wolfgang et. al. ${ }^{(30)}$ (1982) suggested that the decision regarding postoperative weight bearing must be made on individual basis.

In trochanteric fracture the ability to resume ambulation was related to several factors besides simple fracture healing. Compion and associates (1987) indicated that mental status, emotional status and previous functional level are critical factors determining the resumption of ambulation. Cummings and Coworkers (1988) emphasized the importance of social situation, nutrition and chronologic age in restoring ambulatory status.

In the present study we dealt with the patients in their elderly age with poor balance control, poor nutrition, illiteracy, low socioeconomic status and mental confusion were the limiting factors to start with a program of early weight bearing either partial or total.

\section{FUNCTIONAL RESULTS:}

In the present study we treated patients of extracapsular fractures with Dynamic hip screw and proximal femoral nailing. Early range of movement of hip and knee joint, Weight bearing in PFN group compare to DHS group.

\section{DEFORMITY}

In the present study, one patient $(8 \%)$ in PFN group had coxavara $\quad(0-10$ degree $)$ deformity at $24^{\text {th }}$ postoperative weeks while in DHS group 4 patients $(20 \%)$ at $24^{\text {th }}$ and 2 patients $(5 \%)$ at $48^{\text {th }}$ postoperative week had coxavara (0-10degree). In DHS group, 2 patients $(10 \%)$ at $24^{\text {th }}$ and one patient $(5 \%)$ at $48^{\text {th }}$ postoperative weeks had coxavara10-20 degree.

Some patients who needed Rotation of extremity for the satisfactory reduction of fracture at the time of operation developed mild rotational deformity.

-3 patients (15\%) in DHS group while one patient (8\%) in PFN group had internal rotation deformity.

-2 patients (10\%) had external rotation deformity in DHS group while external rotation deformity in PFN group.

-1 patient (8\%) in PFN group had shortening of affected limb between $0-2 \mathrm{~cm}$ while 3 patients (15\%) in DHS group had shortening of limb between 0-3 $\mathrm{cm}$.

\section{INFECTION;-} infection.

-In this study one patient (8\%) in PFN group while 3 patients (15\%) in DHS group had superficial

-In DHS group there were 2 patients (10\%) who developed deep infection while there was no incidence of deep infection in PFN group

-The average incidence of infection in this study was $11.5 \%$

According to available literature, incidence of wound infection in operative treatment of extracapsular fracture upper end of femur varies from 1.7\%-16.9\%

\section{HARDWARE FAILURE-}

In present study, weeks).

-One patient in DHS group had implant failure (broken of DHS plate of 8 holes after $18^{\text {th }}$ postoperative

-One elderly patient in PFN group had cutout of antirotational lag screw at $12^{\text {th }}$ postoperative weeks; it might be due to osteoporosis or poor quality of implant. In majority of cases there were no implant failure in this study

CONCLUSION:In PFN group patients, blood loss and soft tissue dissection was less as compared to DHS group patients. Within first 3 months PFN allowed a faster postoperative restoration of walking ability as compared to DHS. It was found that there was no major difference between PFN and DHS treatment group in long term follow-up in clinical and radiological features. 


\section{BIBLIOGRAPHY :}

1) Harrington, K.D. and Johnston, J.O. (1973): The management of comminuted Unstable Intertrochanteric Fractures. J. Bone Joint Surg., 55A: 1367-1376.

2) Hunter, G.A. (1975): The Results of operative Treatment of trochanteric fractures of the Femur. Injury 6: 202-205.

3) Kuderna, H. et al (1976): Treatment of Intertrochanteric and Subtrochanteric Fractures of the Hip by Ender method. J.Bone Joint surg., 58A: 604-611.

4) Zickel, Robert E. (1976): An Intramedullay Fixation Device for the proximal part of the Femur J. Bone Joint Surg. 58 A: 866-72.

5) Cuthbert, H. et al (1976) : The use of Kuntscher Y-nail in the treatment of intertrochanteric and subtrochanteric fractures of Femur. Injury 8: 135-42.

6) Poigenfurst, J. et.al (1977): Multiple Intramedullary Nailing of Pertrochanteric Fractures with Elastic Nails. Operative procedure and Results. Injury 9: 102-13.

7) Laskin RS et al (1979): I.T. fracture of hip in the elderly. Clinc. Ortho. 101: 110-119.

8) wilson, G.E. et al (1980): The Significance and a Comparative analysis of Epidemiology of Hip Fractures. Clin. Orthop. 152: 35-43.

9) Esser, M.P., et.al (1986): Trochanteric Fractures of the Femur. J. Bone Joint Surg., 68B: 557-560.

10) Kim, W.Y et. al (2001): Failure of intertrochanteric fracture fixation with a dynamic hip screw in relation to pre-operative fracture stability and osteoporosis. Int. Orthop. 2001; 25(6): $360-2$.

11) Harrington P. et al (2002): Intramedullary hip screw versus sliding hip screw for unstable intertrochanteric femoral fractures in the elderly. Injury, 2002 Jan.; 33(1): $23-8$.

12) Saudan, M. et al (2002): Pertrochanteric fracture: is there an advantage to an I.M. nail? : A randomized, prospective study of 206 patients comparing the DHS and PFN. J. Ortho. Trauma 2002 July, 16(16): 38693.

13) Tyllianakis M. et al (2004 Oct.): Treatment of extracpsular hip fractures with the proximal femoral nail; long term results in 45 patients. Acta. Orthop. Belg. 2004 Oct; 70(5): 444-54.

14) Heyse-Moore, G.H. et al (1983): Treatment of Intertrochanteric Fractures. A comparison of the Richards screw plate with Jewett nail plate. JBJS, 65B: 262-267.

15) Rueger, Wu, Chi-Chaun et al (1996): Journal of trauma infection and critical care. 41(4): 699-702.

16) Reska M, Veverkova L, Konecny J. Proximal femoral nail (PFN) - A new stage in the therapy of extracapsular femoral fractures. ScriptaMedica (BRNO). 2006; 79(2):115-22.

17) Cleveland, M. et. al. (1947): Intertrochanteric Fractures of the Femur. J.of Bone and joint Surg. 29: 10491067.

18) Weiss, A.B.; et al. Treatment of unstable intertrochanteric fractures with anatomic reduction and ... J Trauma 18:732-735, 1978. 124.

19) Frangakis EK. ... J Bone Joint Surg Br. 1966 Feb;48(1):17-30.

20) Barnes R, Brown JT, Garden RS, Nicoll EA. ... J Bone Joint Surg Br .1976; 58(1):2-24.

21) Hall, G, et al. (1981): Comparison of Nail plate fixation and Enders nailing for intertrochanteric fractures. J.B.J.S. 63-B: 24-28.

22) Christopher H, Flemming et.al

23) Baker, H.R et.al (1960): Ununited Intertrochanteric fracture of the Femur. Clin. Orthop. 18: 209-219.

24) Sarmiento, A.et.al (1963): Intertrochanteric Fractures of the Femur: $150^{\circ}$ Angle Nail Plate Fixation and Early rehabilitation: A Preliminary Report of 100 cases. J. Bone Joint Surg. 45 A: 706-722.

25) Mulholland, R.C. and Gunn, D.R. (1972): Sliding Screw Plate Fixation of Intertrochanteric Femoral Fractures. J. Trauma, 12: 581-591.

26) Wilson HJ, Ishizuka T. A ten-year analysis ofintertrochanteric fractures of the femur. ... ActaOrthopScand 1980; 51: 811-6. 13.

27) Mariani EM, Rand JA: Nonunion of intertrochanteric fractures of the femur ... Simpson AH, Varty K, Dodd CA: Sliding hip screws: modes of failure, Injury 20:227, 1989.

28) Mariani and Raud 1989

29) Nuber $S$ et al (2003): Stabilisation of unstable trochanteric femoral fractures. DHS with trochanteric stabilization plate versus PFN. Unfallchirurg. 2003 Jan; 106 (1): $39-47$.

30) Wolfgang, G.L et. al (1982) : Treatment of Intertrochanteric Fracture of the Femur Using Sliding Screw Plate Fixation. Clin. Orthop. 163: 148-158. 